
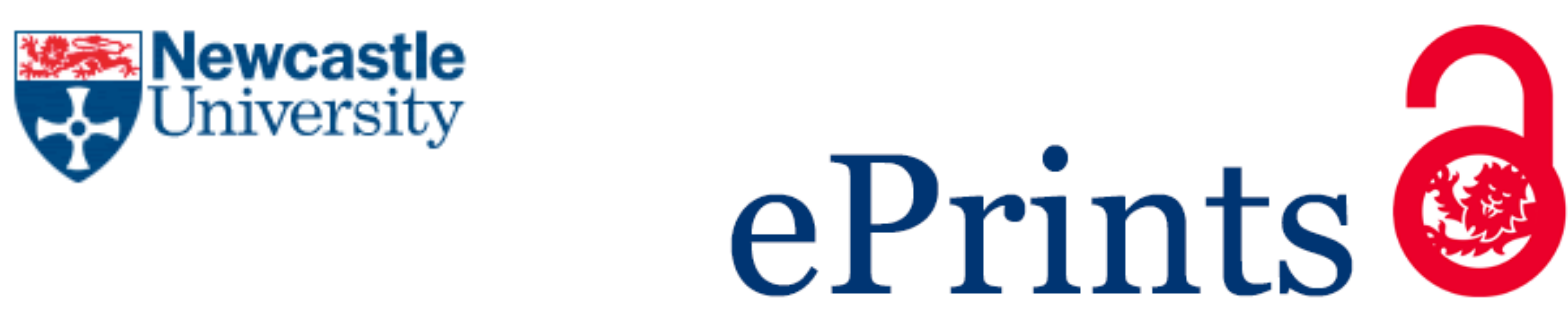

Blazek M.

Migration, vulnerability and the complexity of violence: Experiences of documented non-EU migrants in Slovakia.

Geoforum 2014, 56, 101-112.

\title{
Copyright:
}

(C) 2014. This manuscript version is made available under the CC-BY-NC-ND 4.0 license

DOI link to article:

http://dx.doi.org/10.1016/i.geoforum.2014.07.002

Date deposited:

$05 / 01 / 2017$

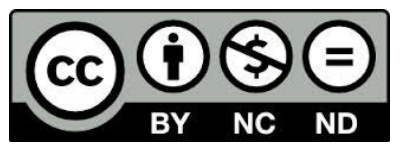

This work is licensed under a

Creative Commons Attribution-NonCommercial-NoDerivatives 4.0 International licence 


\section{Migration, vulnerability and the complexity of violence: Experiences of documented non-EU migrants in Slovakia}

Key words: migrants; violence; Slovakia; East and Central Europe; hate crime; work exploitation

Abstract: Migration to East and Central Europe (ECE) remains under-researched, not least because of the relatively small number of migrants in the region. Exploring experiences of documented non-EU migrants in Slovakia with various forms of violence - including violence motivated by hate and associated with work exploitation - the paper uncovers patterns of violence and vulnerability across the migrant cohort. As a broader contribution to studies of migration, the research alerts scholars to the need for a greater attention to the experiences of smaller cohorts of migrants, which often remain under the radar because of their size. The second line of the argument highlights the complexity and relations between different kinds of violence. Several risk factors are identified as contributing to the risk of migrants' exposure to various forms of abuse at the same time, providing with implications for preventive and supportive policies and practices. The analysis particularly emphasises the importance of ties between migrant communities and formal institutions for mitigating violence.

\section{INTRODUCTION}

In the last decade, East and Central Europe (ECE) has been for the most part conceptualised as a source region of primarily labour-motivated out-migration. The flows of labour migrants from ECE to Western Europe after the accession to the EU in 2004 overshadowed other patterns of migration, drawing considerable interest from geographers (Williams and Baláž, 2008; Burrell, 2008, 2010; Stenning and Dawley, 2009; Findlay et al., 2010; McCollum and Findlay, 2011) and others (Anderson et al., 2006; Spencer et al., 2007; Cook et al., 2010, 2012).

This paper argues that the scarcity of research on the flows of migrants into ECE is consequentially echoed in the lack of understanding of migrants' experiences and livelihoods, obscuring underlying patterns of extensive abuse and exploitation. It demonstrates the importance of in-depth empirical and conceptual inquiry into both migration patterns and migrants' experiences in ECE, highlighting some methodological, conceptual and contextual challenges of such work. As a broader contribution to studies of migration, the paper provides an argument that the scale of migration is not necessarily reflected in the scale of abuse, and even areas with low numbers of migrants require attention that is often given only to those with more numerous flows of migrants.

This is attained through exploring the exposure of migrants from non-EU countries (third country nationals; TCNs) in Slovakia to diverse forms and practices of violence, drawing on findings from a nation-scale research project conducted by the International Organization for Migration (IOM) in 2012. The paper is thus in turn adding also to the existing understandings of migrants' experience with violence and the impact it has on their wellbeing (Black et al. 2006), 
focusing on the complexity of violence. This second line of argument brings together data on migrants' experiences with violence motivated by hate and that associated with work exploitation, highlighting the intersections and complex relationships between the factors of risk and support, and with patterns of social exclusion and marginalisation in the background. The main argument is that certain factors might increase or mitigate the risk of exposure to several forms of violence, which establishes implications for policy and practice to consider prevention and supportive strategies through multi-dimensional lens.

\section{PRESENT FOCUS ON ECE MIGRATION}

All East Central European countries that accessed the EU in 2004 (the Czech Republic, Hungary, Poland and Slovakia) recorded a rapid increase in immigration afterwards, even though this rate decelerated after the outbreak of the financial crisis in 2008 due to the dominant share of flexible labour migration. Nevertheless, they (except for the Czech Republic) still host some of the lowest populations of immigrants within the $\mathrm{EU}$, in both relative and absolute numbers. Yet in the light of expectations that followed the accession to the EU and the geopolitical and economic location of the region, it has been argued that ECE countries should be viewed as 'future immigration lands' (Castles and Miller, 2009, p.116; see also Wallace and Stola 2001; Fassman et al., 2009).

In spite of this, regular migration to the region of ECE remains under-researched as of the present. As an offset to the research agenda of the major East-West migration flows within the EU, return migration of ECE labour migrants from Western Europe has received some attention from the very onset of the post-accession period (Williams and Baláž, 2004, 2005b, 2008; Castles, 2006; Galasińska, 2010; Klagge and Klein-Hitpass, 2010; Cieslik, 2011; Martin and Radu, 2012; Careja and Emmenegger, 2012). Less so, researchers have attended to irregular migration and migration of refugees to ECE (Drbohlav and Janska, 2009; Klvanova, 2010; Pikhart et al., 2010; Maroukis et al., 2011; Medova and Drbohlav, 2013). Only very limited amount of work then specifically targets regular migrants in ECE, particularly those from outside the EU. The work of Williams and Baláž on the transnational spaces of Vietnamese petty traders in Slovakia (Williams and Baláž, 2005a; Baláž and Williams, 2007), Górny's and Kępińska's (2004), Veermersch's (2007) and Triandafyllidou's (2009) studies of the mobility of Ukrainian migrants in Poland and Hungary, and Cook's $(2010,2011)$ research on the geographies of transnational elites in Prague, are among the few examples of in-depth research into migration patterns and everyday experiences of non-EU migrants in ECE. Yet these studies focus on single groups of migrants from a particular angle and little is known conceptually about the diversity of migrants and their experiences in the region. In this context, only work of Williams and Baláž targets migration from and to Slovakia.

This paper responds to this lacuna by providing a comprehensive overview of the migration context in Slovakia, drawing on an extensive original fieldwork as well as existing datasets. Emphasising the wellbeing of migrants rather than migration patterns themselves, the focus is on the vulnerability of migrants in Slovakia to various forms of violence as an emergent and under-researched issue. 


\section{CONTEXT OF VIOLENCE: CONCEPTUAL FRAMEWORK AND RESEARCH SCOPE}

As Lawrence and Karim $(2007,10)$ argue, "[t]here is always a context, or a structure, to violence". Theorising violence requires examining much more than the physical act of ferocity itself, as the relevant context might range from the conceptual spatialities of military conflicts (Gregory 2010) to the "waves" of emotional experiences and practices contesting domestic violence (Pain 2014). This paper maps experiences of (documented) migrants with actual physical violence, but first and foremost it explores the context of vulnerability that increases the risk of exposure to violence and inflates its consequences. This includes various patterns of social exclusion, marginalisation or discrimination that often create a pillar or framework for violence themselves (Reed et al. 2010; Rafferty 2013), but the focus of the paper is also on experiences of violence not necessarily related to migrants' socio-legal status, as how they are mitigated reflects back on the patterns of inclusion and exclusion experienced by documented migrants in Slovakia. This is also why the paper explores relations between violence and migration without looking at where violence is likely most prominent: experiences of displaced persons, victims of human trafficking or refugees (Huang and Yeoh 2007; McGrath 2013). Whereas the relations of vulnerability and exploitation are more obvious in these contexts, the paper intentionally looks also at perhaps more subtle forms of violence, abuse and exploitation as a way to shed light on patterns of injustice associated with documented migration, and often overlooked, particularly in the context of ECE.

The World Health Organization (WHO) defines violence as:

"The intentional use of physical force or power, threatened or actual, against oneself, another person, or against a group or community, that either results in or has a high likelihood of resulting in injury, death, psychological harm, maldevelopment or deprivation." (WHO 2002, 4)

Of various facets implied in this conceptualisation, three are of particular importance. First, abuse of a power relationship, threats, pressure, neglect and maltreatment, all need to be seen as manifestations of violence, not only the physical act itself. Second, violence does not have to result in physical injury as the harm can be psychological or social, and it can manifest only after a longer period. Finally, the intentionality of the act is crucial for identifying the act as violent, even if there is a mismatch between the actual and intended consequences.

The paper thus does not only directly explore acts of violence, but, emphasising the complexity of violence, it explores also perceptions and threats of violence, their consequences, and the intentions behind such practices. Further, recognising the importance of the context of violence, it associates these with the socio-economic and legal circumstances of migrants, highlighting the risk and mitigating factors. It recognises that there might be a tension between various definitions of violence and its subjective perceptions by victims and that particular acts of violence can be viewed differently by various actors besides migrant communities, such as policing and helping institutions or media (Jewkes et al. 2002; Benson 2008). It looks at practices associated with physical violence that are often labelled as abuse or exploitation, paying attention to the presence of violence, actual, threatened or perceived. By exploring the importance of violence in the experiences of those migrants who are usually deemed to be less prone to violent abuse, the paper identifies overlooked patterns of vulnerability, marginalisation and social exclusion. 


\section{MIGRATION AND VIOLENCE}

Migrants can be more prone to abuse and exploitation than the host population for a variety of reasons. Migration itself is often an attempt to address one's own vulnerability and disadvantage (Brainard et al., 2009; Raleigh, 2011). Migrants can be at a handicap in relation to the host society because of the cultural capital they establish (Erel, 2010) or the lack of acceptance from the host society (Manevska and Achterberg, 2011). They can become vulnerable not just because they lack resources, but because they might not be aware of them. Moving to a new locality also means a relative loss of social capital for many migrants in comparison with their long-term place of residence (Cheong et al., 2007). Diasporas and migrant communities, ties with individuals from the host society (for instance through churches or workplace) and effective institutional interventions can mitigate this disadvantage, but social isolation is a key element of the risk of exposure to violence for many migrants. Migrants' legal and political status can further limit their rights and opportunities (Bloemraad et al., 2008) as the limited permit to stay or have a job, restricted access to welfare system or restricted movement are among the disadvantages that can lead to further abuse and exploitation. Finally, the move to a new country itself, or a change of setting, can lead to an economic handicap which can translate to the risk of abuse. A combination of these factors, or a significantly strong presence of some of them, triggers the most notable patterns of vulnerability.

Many forms of violence, abuse and exploitation experienced by migrants can be based on similar patterns to those acts experienced by individuals from the host society. However, migration can be still an important analytical element that accounts for specific relations between the risk of violence and its presence, or between the victim and perpetrator. Drawing on the existing literature, several main areas of violence towards migrants can be highlighted, of which I am focusing on the two that will be further discussed in the empirical part of the paper - hate-motivated violence and violence associated with work exploitation.

The last decade has given rise to new formations of violence motivated by hate that are "fuelled by political rhetoric portraying immigrants, refugees, and minority populations as security threats, cultural interlopers, and economic encumbrances" (McClintock, 2005, i.). Whereas in the years following 9/11, narratives of security prevailed in the emerging climates of anxiety (Ernst 2013), economic scarcity and access to resources (Dancygier, 2010) have now turned to be dominant in targeting migrants as scapegoats for an array of "social ills ranging from crime to unemployment" (Human Rights First, 2008, 16). Whilst the class theory gives an explanation for the formations of hate motivated violence as "embedded in neoliberalism [and] set against a backdrop of globalisation... where the poor and poorer still are left to fight it out over deregulated employment, as social protections are steadily eroded" (Burnett, 2013, 6), the "common sense racism" (ibid., 7) against immigrants looks to be underpinned by a much wider span of narratives, including those about "unequal treatment of one group by the other, or competing value systems that threaten our understanding of the world" (Rabrenovic, $2007,349-350)$. The very notion of difference, substantiated by the migration status or origin, is the principal factor behind the violent act and vindicated opportunistically. 
Second, many migrants are vulnerable agents in the work environment and labour markets. The importance of the socio-legal status cannot be underestimated (Dwyer et al. 2011), yet diverse groups of migrants have been identified as especially prone to exploitative practices, ranging from borderline legal exploitation to serious violent acts with lethal consequences (Anderson and Rogaly, 2005; Craig et al. 2007; Clark 2013). Whereas in practice, much of the serious abuse related to work is being subsumed within the human trafficking agenda, research has shown the need to consider experiences of work exploitation, abuse and violence as a continuum in order to "describe the complexity of the exploitative environments and concrete individual situations of workers" (Skrivankova, 2010, 4), and to develop appropriate policy and practice measures (Geddes et al. 2013). As labour exploitation of migrants is intrinsically linked to other important themes of population and migration studies, such as economic and social diaspora connections (Meyer, 2001; Cohen, 2005; O'Connell Davidson, 2013), or population change and transformations of labour market (Barrell et al., 2010; Longhi et al., 2010; Glitz, 2012), vulnerability of migrants in the work environment needs to be seated at the centre of social studies of migration.

The remit of this paper is to identify primarily the overarching patterns of vulnerability and agency among the migrants and how they generate circumstances for violent acts, and to consider the complexity of how violence against migrants is constructed and experienced in the public (regarding hate-motivated violence) and in the workplace. Other forms of violence are often embedded in, or interrelated with, these two areas presented, including domestic (Fernandez-Esquer and Diamond, 2013; McGrath 2013), symbolical (Bryan, 2009; Moukarbel, 2009) or institutional violence (Jácome, 2008; Alvarado and Massey, 2010; Barbeiro and Spini, 2011), and while these could not be included in the paper for the lack of space, they will be reflected where relevant connections emerge.

\section{MIGRATION TO SLOVAKIA AND MIGRANTS IN SLOVAKIA}

Factors that underpin the significance of situating this research in Slovakia include the relatively small migrant population, largely overlooked by academic research and placed in an underperforming institutional environment. This gives a good sample for studying the complexity of the vulnerability of migrants to various forms of violence and their interrelations, while at the same time the context of Slovakia resembles those of other countries in the region and the research can contribute to the emerging scholarship on migration and migrants' experiences in ECE.

Slovakia remains a country with one of the lowest numbers of migrants within the EU and one largely overlooked by international scholars (see Williams and Baláž, 2005a; Baláž and Williams, 2007 for an exception). Despite the considerable growth of the migrant population after the country's accession to the EU in 2004 (Divinsky 2009), Slovakia retains the third lowest number of TCNs in the EU, absolute and relative, with the TCN population just over 26,000 and making $0.5 \%$ of the total population in 2011 . Besides, the dynamics of in-migration has decelerated since 2008 after the financial crisis impacted on employment and 
entrepreneurship opportunities in the country, even though the numbers of immigrants are still rising.

Slovakia has been subject to critique nationally (Divinský 2011; Chudžíková 2011) and internationally (MIPEX III; GRETA 2011; US State Department 2012) for various stances of the legislation, migration policies and institutional frameworks relevant to migration. The national policy has been since 2011 based on a philosophy of migration management focussed on migrants with high qualifications who come from "culturally adjacent countries". The institutional landscape of the state engagement with TCNs is restricted to the bodies that regulate migration (Immigration Police, Social Insurance Office, Labour Offices) whilst support activities are outsourced to the non-governmental sector, using predominantly resources from the European Fund for the Integration of Third Country Nationals (EIF). The existing services, run on a project basis by local NGOs and other actors, are limited to the provision of information and legal consultancy with a minimum of resources addressing outreach activities. This leaves the relationships between public institutions and migrant communities stark. Slovakia lacks a civil institution of the first contact that would act as a complex hub of information and services (a one-stop centre). As the agenda of the National Labour Inspection is focussed on tackling illegal work and the trade unions are not active in the protection of migrants, an institution dealing with the labour rights of the migrants is absent. There is very little engagement in the areas of community work and organisation, community education, and further resources from the EIF tend to address the wide public and intercultural activities rather than the most vulnerable groups of migrants (Blazek et al., 2013). Research on migration is restricted to projects funded by the EIF and run by the third sector, being at the margins of academic interest.

For most migrants in Slovakia, work is the key motivation for moving to Slovakia. Over $70 \%$ of TCNs are in the productive age (compared to just $55 \%$ of the overall population in Slovakia) and $41 \%$ of TCNs are within the $25-39$ age category. It has been estimated that work is the primary motivation for almost half of TCNs and in three of the five most numerous groups of migrants (Ukraine, Vietnam and China) that represent $40 \%$ of all $\mathrm{TCNs}^{1}$ (see Table 1), it is the main motivation for over $70 \%$ of adult migrants (Blazek et al., 2013). Over $70 \%$ of all TCNs have some experience with work in Slovakia but in these three groups the proportion is between 80\% (Ukraine) and 95\% (China).

\section{[TABLE 1 ABOUT HERE]}

The largest groups of TCNs in Slovakia are as follows ${ }^{2}$ :

Migrants from East and Southeast Europe represent the most numerous group of TCNs, with those from Ukraine, Russia and Serbia making up over $50 \%$ of all TCNs. There are some significant differences between these groups, however. Ukrainians come mainly for employment, many leaving their families at home and transferring remittances. Studies and/or family life are a much more common motivation for Russians and Serbians. Serbians are the largest group of university students among the TCNs and with a relatively high qualification

\footnotetext{
${ }^{1}$ When discussing results of the research, only adult migrants are included in the category of TCNs.

${ }^{2}$ The ensuing characteristics are based on the day-to-day contact work of the IOM with migrants from non-EU communities and they are results of the participation of practitioners in the research project in the advisory, facilitating as well as the field work role.
} 
and economic capital they tend to be economically active as entrepreneurs. Similar patterns can be seen among Russian migrants although family connections are a more important factor than it is in the case of Serbians. All East and Southeast European migrants bring an important asset in their language abilities as Slovak is similar to other Slavic languages. Their physical appearance and cultural customs also make it easier for these migrants to blend within the majority, predominantly white Slovak-nationality population.

Migrants from East and Southeast Asia are a group with some similarities and some differences among the individual cohorts. Work is the main motivation for all groups, but whereas the migration of South Koreans was triggered by huge investments (KIA and Samsung industrial complexes) supported by the Slovak government, Chinese and Vietnamese migrants are small entrepreneurs, bringing along their relatives as labour force. Some other migrants, such as Thais and Indians, come to Slovakia for work in a specific industry (massage saloons, restaurants) with little economic capital. Migrants from East and Southeast Asia are organised in their own communities (unlike migrants from Slavic nations who tend to cope with their livelihoods individually) but they are also the most isolated groups of migrants, with the lowest levels of interactions with the host society, knowledge of the language, legislation or culture.

About 1,300 TCNs come from Minority World Anglophone countries, mainly the US, and to a much lesser extent Canada, Australia and New Zealand. We also include South Africans in this cohort as the majority of migrants from this country are Anglophones working for transnational companies. This group mostly consists of educated and highly qualified migrants who either take high-skills jobs in Slovakia, or have the sufficient social and cultural capital, flexibility and economic sources to live in Slovakia as a lifestyle decision. They can be characterised by high mobility and a good level of informal organisation, mainly through social hubs (workplace, pubs or church) and on the internet, which helps them meet their everyday needs and resolve their problems.

Migrants from the Middle East and Maghreb, but also other Muslim migrants (e.g. from Albania or Somalia) are mostly organised within one of the religious communities devoted to Islam. In comparison to other groups of migrants, they form a very compact community (unlike the Anglophone migrants) and focus on supporting their members and their well-being rather than primarily on economic activities (as in the case of migrants from Vietnam or China), regardless of the family or workplace relations between the migrants (such as with the migrants from South Korea or other East Asian countries). They have been targets of the greatest deal of hostility within the Slovak society over the last decade as a result of the global Islamophobic trends, even though no open conflict at a larger scale has escalated. The distance between the Muslim communities and the majority society, and the tendency of the communities to stick together are very important features of Muslim migrants.

Other groups and communities of migrants are much less numerous and often share various features of the communities discussed above.

\section{METHODOLOGY AND PRACTICALITIES OF THE RESEARCH}

This research was funded by the EIF and it drew on the existing practice of the IOM in Slovakia with TCNs. It aimed to explore the magnitude and patterns of violence against TCNs in 
Slovakia, identify risk and protective factors and evaluate the existing legislation, policies and practice in the country.

Methodologically, the project was tackling two key challenges:

First, there is a lack of empirical base and secondary data on migrants in Slovakia. The publicly available datasets come from the Statistical Office of the Slovak Republic and from the "Alien" Police Department (immigration police). These give a complementary view on the country of origin, age and gender of immigrants but they are not entirely compatible and other variables, such as about economic activity, family status or education, are not collated. There was also no statistical overview of migrants as victims of crime (although datasets exist about migrants as perpetrators). The limited number of policy-focused studies on TCN migrants in Slovakia either explored the host society in relation to migrants or drew on smaller and selective samples.

Second, we aspired to address particularly the most vulnerable and isolated migrants. This proved to be the main challenge of the research, ethically, epistemologically and practically (cf. Van Liempt and Bilger, 2009, 2012). The lack of institutional bonds between the formal sector and migrant communities made it difficult to draw on the existing ties and relationships so we had to reach out actively to various communities and sub-communities of migrants. The praxis of the IOM as the helping organisation with the largest coverage of migrant communities in Slovakia proved to be central here, but large numbers of migrants, especially from groups that are not organised in communities, remained out of reach, including some of the most numerous (Ukraine, Russia) or vulnerable (Thailand) groups. The fragmentation of the migrant communities, apart from itself being a risk factor of the exposure to abuse (Sabates-Wheeler and Waite 2003), was thus a methodological problem too. We also had to consider the relationships between the migrants themselves and their power dynamics. We did not want to utilise only the existing ties with the gatekeepers from migrant communities which we believed would have involved only a limited sample of migrants. We reached out also to new contacts and networks, often bringing in only a small number of participants but from isolated groups. At the same time, we wished to tackle possible conflicts of interest among the migrants themselves, for example by not relying exclusively on migrant elites if we could not be entirely sure they did not contribute to the marginalisation of other migrants.

The research drew predominantly on a questionnaire survey addressing the whole population of TCNs, and a series of semi-structured interviews with individual migrants, migrant representatives and other actors with an understanding of, or contacts with, migrant communities. The questionnaire, translated into 11 languages, included 137 questions covering the socio-demographic profiles of the respondents, their accounts of experiences with violence and abuse in Slovakia, and sets of questions that explored experiences with particular areas of violence, abuse and exploitation. These were collected in hard copies and online through a network of Field Mediators (see below) and direct contacts of the IOM practitioners in migrant communities, as well as through key stakeholders such as embassies, universities or cultural centres. 83 interviews were conducted in total with migrants from 32 countries and Slovak citizens. The interviews differed in shape - whilst interviews with Slovakians (activists, practitioners, interpreters or other persons involved with particular migrant communities) addressed mainly their knowledge of others (migrants), interviews with 
migrants addressed interviewees' personal experiences as well as their knowledge about their communities.

The fieldwork was based on collaboration with an extended network of associates. Apart from drawing on gatekeeping from other professional organisations and capacities of colleagues from other IOM projects, the main device was our collaboration with "Field Mediators" (FM). FMs were mainly engaged representatives of migrant communities, but also other individuals with contacts among migrants, such as interpreters, individuals from churches, cultural centres, shops, restaurants or embassies. The role of FMs was to help with the questionnaire collection, but also to spread the information about the project and its context (migrant rights, existing sources of support), and to mediate the contact between individual migrants and the IOM with its services. For some participants, the encounter with the research brought an important piece of information about their rights which in several cases led to an involvement with other IOM programmes, including cultural programmes, legal consultations or the counter-trafficking unit. By involving the FMs who were also bound by the ethical code of the research, we ensured double anonymity, where the research team had no contact with the questionnaire participants whilst the FMs had no access to the information (as the questionnaires were completed online or delivered to the FMs in a sealed envelope).

The participation of migrants in the research was thus boosted particularly by:

- involvement of trusted community members;

- emphasis on transparent ethical mechanisms, including a strict "opt-in" principle of participation and the primacy of anonymity (no informed consent was signed and the interviews were not voice-recorded, rather undertaken by two investigators who took notes);

- availability of accessible language versions of the questionnaire and to an extent also at the interviews;

- migrants' perception of the integration of research and practice within the project due to the direct and indirect involvement of IOM practitioners;

- immunities and privileges of the research team due to the IOM status as an intergovernmental organisation, which guaranteed us an exception from the legal obligation to report minor illegal activity (such as undocumented stay or work).

On the other hand, we encountered various challenges that limited the scope of the research and at the same time serve as prompts for further work. They are largely a result of the limited resources to reach out to some of the most vulnerable groups of migrants, given the need to establish a steady relationship first, and of the non-existent institutional engagement that would facilitate it. These include especially a lack of follow-up interviews with migrants from Asian communities and with actual victims of serious violent act, particularly domestic violence. The accounts of these thus come mainly from the questionnaire survey (where we covered also a number of qualitative accounts of experiences of such victims) and from interviews with other migrants or practitioners.

Overall, we collected 730 questionnaires, 40 of which came from migrants with an EU citizenship or asylum seekers and holders (who were not the target group of the research). The remaining 690 questionnaires represented over 3\% of the overall TCN population, although with some disproportions among particular groups, caused by difficulties to cover especially 
the most numerous and individualised groups of migrants (from Ukraine, Serbia and Russia) proportionally and by our allocation of research resources towards the more vulnerable groups of migrants (especially those from Thailand, Muslim countries and Vietnam). We therefore allocated coefficients of weight to the largest groups of respondents (by the country of origin and gender), resulting in the overall weighted $\mathrm{N}=729$, achieving a proportional representation of male and female (separately) migrants from Ukraine, Serbia, Russia, Vietnam, China, South Korea and countries of the Maghreb and Middle East (as a single group).

\section{MIGRANTS IN SLOVAKIA AND VIOLENCE}

\subsection{Context of vulnerability: migrants' bonds and resources}

An important risk factor for the migrants is the configuration of bonds and sources of support they can rely on. In our research, $16 \%$ of all migrants stated that they did not feel accepted in Slovakia, with the number among migrants from Eastern and Southeastern Asia almost twice as high (29\%). Only $46 \%$ of all migrants believed that they had the same rights as the Slovak citizens and only $38 \%$ thought they had the same opportunities. Three central factors of disadvantage as stated by the participants from all countries were the country of origin, legal status in Slovakia and language skills, while others (e.g. ethnicity, economic situation, education, religion) were important to a different degree in individual communities, as illustrated in the following three extracts:

'Living in Slovakia, if you don't speak the language, are foreigner, and even of a different colour of skin, is... difficult.' (Male from India, age 30-34)

"It is different to "live here" and "visit". They are nice at first. They like you up to the point when you become real.' (Female from USA, age 25-29)

'People in Slovakia don't like foreigners. Especially if you are dark and Muslim.' (Male from Egypt, age 30-34)

This was further translated into a lack of trust in formal institutions. Only $28 \%$ stated that they approach formal institutions in case of problems whereas $74 \%$ turn to informal contacts. $43 \%$ of migrants said that they had never used any institutional service. Of those who had ever used an institutional service, $25 \%$ said that they had never been satisfied with the help whilst only $8 \%$ gave the same answer about informal sources of help.

The most striking issue comes from the answers given by actual victims of serious forms of violence and abuse ${ }^{3}$. Tables 3-6 demonstrate that the contact of these vulnerable migrants with formal institutions, usually the only ones with best capacities to provide qualified help

\footnotetext{
${ }^{3}$ These categories were identified on the basis of experience with certain practices of forced labour and domestic violence respectively, i.e. victims were not self-identified. To identify victims of forced labour, we followed the established ILO indicators (Skrivankova, 2006; see part 7.4 for more details). For domestic violence, after consultation with a local supporting group, we established 11 experiential and 5 emotional indicators, a combination and occurrence of which indicated domestic abuse.
} 
because of the seriousness of the violent act and its effect, is rather limited and the level of support is poor.

\section{[TABLES 3-6 ABOUT HERE]}

These numbers offer some important conclusions. First, medical services are the institutions with the strongest bonds with the migrants. However, they also have only limited capacities in providing support beyond the medical scope (psychological, social, financial). Second, nonstatutory agencies (helping organisations) in Slovakia too have only limited bonds with migrant communities and they are not successful in reaching out to the most vulnerable individuals (corresponding to the narrative in section 5). Third, the police display some of the lowest rates of bond and trust from the most vulnerable migrants, despite being the first-contact institution and the agency with most power and responsibility for tackling violence.

The two key reasons for this detachment are migrants' experiences with inadequate forms of behaviour from formal institutions and a systematic exploitation of migrants in some communities, including discouragement from contacting these institutions. The first problem includes experiences with such forms of behaviour as unwillingness to communicate in a language other than Slovak or secure an interpreter (experienced by $51 \%$ of migrants with any contact with formal institutions), refusal to help at all (48\%), refusal to communicate at all (41\%), disrespectful behaviour (37\%), intentional misleading (37\%), bribery (26\%), shouting (24\%), threats (20\%) but also physical violence at the institution itself (6\%). Efforts by other community members to prevent contacts with formal institutions will be explored in more detail in section 7.4.

\subsection{Migrants' perception of violence and its implications}

Table 2 demonstrates some key differences between the perceptions of violence held by particular groups of migrants, particularly:

- $\quad$ higher perception of safety among European migrants than those from Asia;

- higher perception of violence as a problem among Asian migrants;

- more experience with violence by migrants from Muslim and African communities;

- in contrast, lesser rates of fear among Asian migrants than those from Europe.

\section{[TABLE 2 ABOUT HERE]}

With support from the qualitative data, this comparison offers the following findings:

First, the feeling of safety does not necessarily correspond with an actual experience of violence. Participants from Asian communities illustrate that violence can be largely avoided through extensive preventive strategies but this still might have very adverse effects on their everyday wellbeing. As an illustration, only $7 \%$ of Koreans mentioned any experience with violence but $40 \%$ consider it a problem for them. Participants from Asian countries mentioned preventive techniques such as living in communities or safe buildings (with reception, flats in high-rise buildings with several locks), or avoiding public transport and individual movement in public spaces. Participants from the Chinese community mentioned home education or bribery of teachers at school so they take extra care as a common practice of preventing bullying of their children. Even migrants from Eastern Europe, the group culturally and visually most 
resembling the majority population, tend to avoid using their native language in public. Despite limited experience with actual violence, just the perception and conception of it affects migrants' lives negatively:

'When I moved with my family to Slovakia in the 90's, I was a victim of verbal abuse by other children in the school and neighbourhood. They laughed at my origin and attacked me. I did not even know them and they shouted "Alien!" at me. However, I must admit that this was much easier as I grew up - nobody attacked me at high school and university. Perhaps it was just a child bullying. However, even now I find myself in situations when I think twice whether I should use my native language in public.' (Female from Ukraine, age 25-29)

These findings support the understanding that the fear of violence and perception of danger are extremely important for the formation of constraints in everyday socio-spatial activities as well as a broader emotional wellbeing. While these aspects have been well recognised in debates concerning gender (Pain, 1997; Koskela 1997; Mehta and Bondi, 1999; Brownlow, 2005), age (Pain, 2006; Bromley and Stacey, 2012) or ethnicity (Pain, 2001; Ehrkamp, 2008; Sandberg and Tollefsen, 2010), migration history and a different place of origin also needs to be considered as relevant factors of social difference triggering such constellation. Mehta and Bondi $(1999,67)$ show how the "management" of danger needs to be understood "in terms of the discursive production and reproduction of gendered identities" and the same should be considered regarding the experiences of migrants. Embodied identities (manifested in the bodily difference or use of different language) along with discourses of difference, danger and safety (in the community and media) with regards to particular spaces are as impactful on the everyday lives of migrants as their direct experience with violence.

Second, migrants tend to compare their experience in Slovakia with their country of origin. Migrants from Muslim and African countries in particular stated low levels of feeling safe in Slovakia but in comparison to other migrants they do not see violence as a problem for them. Interviews gave us insights into how some migrants relativized their perception of violence in Slovakia, including those who had experienced conflicts in their countries of origin, who had been in danger in their previous country of stay because of their ethnicity (e.g. some Asian and Muslim migrants who moved to Slovakia from Russia after experiences of hate-motivated violence) or those from countries with a high level of crime (e.g. South Africa). Migrants thus might reflect on their actual experiences with violence differently from the majority population because of the different sensitivity to violence and expectations on safety based on their individual history, a finding that urges us to explore all understandings of violence (including the dominant ones such as in national legislation and policies) as always reflecting the situated and constructed models of social relations, rather than universally translatable truths (see Welch, 1990). In addition, some migrants tended to trivialise the causes of violence, to take some blame for it or to find excuses for the perpetrators, as the following example illustrates:

'I don't know if this should be seen as violence. Me and my husband and verbally abused because of our faith and because of me being a foreigner. Some are indirect, hints, some are just insults. Nobody 
attacked me physically but I admit I am much more afraid since I have been wearing the Muslim scarf... For some time, I had to take it off because I could not find a job. Now it is a year since I carry it again and I experience those hostile looks and reactions. But I also must praise some people as they are very empathetic and considerate. They accept me as normal, but they are not many.' (Female from Ukraine, age 35-39)

Whilst this participant emphasised an experience of hostility and abuse because of her difference, her narration also illustrates the tentativeness to self-identify as a victim. Drawing on parallels from the studies of domestic violence (Felson and Paré, 2005; Shernock, 2005), the hesitance to articulate one's experience as a violent act often also triggers the hesitance to report such experience and seek help as a victim of violence, highlighting the urge for a proactive approach to identifying and challenging violence towards the more vulnerable and isolated social groups, such as through third-party reporting systems and a wider range of supporting institutions beyond the justice system.

\subsection{Violence motivated by hate}

When asked about violence, and given that the research was presented as an inquiry into "migrants" experiences, most participants tended to first associated violence with acts motivated by hate and prejudice. While not the only context of violence experienced by migrants, it exemplifies very well the importance of both direct experience and perception of violence, and of various facets of social difference in the construction of violence.

Migrants from essentially all groups have experienced violence motivated by hate, but most experience was stated by migrants who can be most easily differentiated as foreigners, i.e. from Muslim and African countries (see Table 7). These two groups of migrants did not experience only the highest frequency of physical attacks but also the most severe brutality. $81 \%$ of physical attacks against Muslim migrants motivated by hate caused an injury (compared to $64.5 \%$ of all physical attacks against migrants) and $25 \%$ of attacks against African migrants led to a serious injury (compared to $6.2 \%$ of all physical attacks against migrants).

\section{[TABLE 7 ABOUT HERE]}

Recognition of difference thus emerges as an important trait of the production of violence. Violence motivated by hate has its focus on a social and embodied characteristic of the victim rather than his or her individuality. It can thus have a broader effect not just on the individual victim but also a whole community or social group to whom the message is directed (McClintock, 2005) and this can encourage other assailants (HRF, 2008; FRA, 2012). Both factors then increase the negative impact of the perception of violence as discussed in the previous section. In the context of the lack of trust and acceptance experienced by the migrants, experiences of threats and hostility that might signal the risk of physical assault are as important to consider. Table 8 shows migrants' experiences with verbal abuse which confirm the low level of experience with violence in public by East and Southeast Asian migrants, largely given by their effort to avoid dangerous situations and their attachment to the community. However, the analysis also identified that men from Ukraine also frequently 
experience hostility and abuse because of their difference. In their case, attacks usually follow the use of their native language in public which identifies them as Ukrainians and triggers a prejudice-based abuse, although rarely with physical consequences.

\section{[TABLE 8 ABOUT HERE]}

The effects of violence motivated by hate should be seen in the light of migrants' perception of being expelled by the majority and their lack of trust in formal institutions, explained in section 7.1. Even without any direct experience with violence, migrants' everyday lives are negatively impacted by the knowledge of attacks against other migrants, bystanders' ignorance or mundane hostile remarks, such as illustrated in the following extract:

'Easier to recognise difference, more problems it brings... I travelled by a tram one day and there was a man with dark-coloured skin, a foreigner apparently... Old and young people, everyone was staring at him... I had an urge to stand up and scream: Hello! Still a person, still a person!' (Female from New Zealand, age 26-30)

Overall, it is primarily the embodied difference itself that triggers hostility and threats of violence rather than the recognition of a particular identity of individual migrants (see Chakraborti and Garland, 2012). A range of narratives about difference - associated with ethnicity, religion, culture and access to resources - are becoming personalised within the unified status of migrant (or "foreigner"), as a target of hostility and, particularly in the cases of difference that is visible and most obvious, even physical violence.

\subsection{Violence related to work}

The utmost importance of work in everyday lives of migrants in Slovakia amplifies the significance of their experiences with work exploitation and of the presence of violence in it. It has been recognised that the disadvantage and marginalisation of some migrants can push them to illicit labour activities or they can accept conditions that would be seen as humiliating or exploitative in their country of stay but might exceed the conditions in their country of origin (Allamby et al., 2011). The lack of knowledge about one's rights is an important aspect of the philosophy of 'negative protection' that expects the victims of work exploitation to look for support on their own as the primary mechanism (Balch, 2012; BERR, 2008).

The key focus here is on the six indicators of forced labour as identified by the International Labour Organization (ILO, 2009 - see Table 9). Drawing on the methodology of Anti-Slavery International (Skrivankova, 2006), the analysis presumes that the presence of more than one indicator is a sign of forced labour whilst one indicator exactly states a high risk. We estimated that one in nine migrants in Slovakia has experienced forced labour, with huge differences among individual groups according to the country of origin and secondarily also gender. The number is highest among the most numerous group of migrants - men from Ukraine.

\section{[TABLE 9 ABOUT HERE]}

We also explored other practices of exploitative labour (see Table 10). The key issue seems to be the length of work hours as over $40 \%$ of migrants work more than 48 hours a week on average. Additionally, 55\% of them state an experience with at least one other indicator of 
forced labour and $25 \%$ mention at least two, suggesting that long work hours are related also to more serious forms of exploitation.

\section{[TABLE 10 ABOUT HERE]}

Exploring the data in more depth, there are very few groups of migrants who are not at risk of work exploitation, such as highly-skilled employees of transnational corporations, scientists and academics, specialists (e.g. chefs from Japan) or priests and deacons. However, even educated migrants with good economic and social capital and English language ability can find themselves in troubles. Examples include experiences of language teachers who, due to the lack of awareness about the law and culture, realised after a few months (not receiving salary) that their employers did not meet their promises and obligations and they were actually working in Slovakia illegally.

The most vulnerable groups are migrants from Ukraine, China and Thailand. The situation of all three cohorts reflects their social contexts in the country and illustrates the links between migration and migrants' livelihood. Workers from Ukraine usually work in low-paid jobs such as construction (men), warehouses and restaurants. All affairs in Slovakia, from the mediation of work through travel to accommodation, are managed through the so-called "Client System" by individuals from the Ukrainian community who have the relevant contacts and knowledge, often in liaison with Slovakian agents, such as lawyers and landlords. Such a service is usually paid and the "Supervisors" (informal term for the role in the community) request that the migrants follow their instructions and discourage them from contacting formal institutions.

'Those households... It's not a household, it's a different regime. More like a prison. Some of those migrants there, they are not migrants, they are the Supervisors. People come to the apartment to sleep in shifts, some stay on the floor. There are 'hygienic rules', fierce regime... and yes, then violence too.' (Male, Ukraine, Age 3135)

Experiences of Ukrainian men highlight violence as a mechanism underpinning power relations in the sphere of exploitative migrant labour (Shechory et al. 2010). As literature shows, the networks of agents who exploit migrants are usually complex, involving members of the host society as well as individuals from migrant communities (Kloosterman and Rath, 2003; Wayland, 2011). For the most vulnerable groups of migrants, such as those from the abovementioned countries, work is the key element of their livelihood in the country in multiple ways - the employer often provides accommodation and food and is the mediator of information about law, social and medical services, generating extremely uneven power relations (Scott et al., 2012). The isolation and non-existing social capital can lead to further exposure to violence through the dependency on external agents who are outside any transparent system (Kagan et al., 2011).

However, the quoted experience of Ukrainian migrants also prompts the attention towards the complex spatialities of vulnerable migrant workers' everyday lives. In a separate part of the research, focused on violence in the private space, we identified that one in seven men from Ukraine had experienced violence by other household members, including cases of sexual assault. Although the acts and other features (including the emotional experience) resemble the patterns of intimate partner violence, this violence is actually committed by co-workers 
and workplace superiors rather than family members or intimate partners. Similar experiences were recorded by female migrants from Thailand and to a lesser extent also women from Ukraine and some migrants from India and China (although in these cases there can be a family relationship between the abuser/employer and the victim/worker). Accommodation for these groups of migrants is usually provided by the employers but the migrants also need to accept the imposed regime. These migrants often experience confinement, control of activities and threats, but also physical violence. They are characterised by a strong economic motivation to maintain their job, low social and institutional ties and limited opportunities to build any (because of the language, lack of trust or semi-documented status), lack of financial means, negative experiences with the police or other institutions and a strong pressure from the employer/abuser.

For instance, female migrants from Thailand, a smaller but extremely vulnerable group of migrants, work predominantly in massage saloons. Although the circumstances vary and in many cases, the work and agreements are fair, many depend on the employer socially and economically and strive to avoid conflicts or confrontations. They work long hours and beyond the content of their contract, but they also experience confinement at the workplace, wage reduction, or health risks associated with their work. In parallel, $26 \%$ mentioned repeated experience of physical violence in their household, while these two experiences mostly come from a single pattern of socio-spatial relations. Similarly, migrants from China usually live in a self-contained community in which the leaders liaise with Slovakian agents such as lawyers, interpreters or doctors. The arrival in Slovakia is usually voluntary and arranged through informal contacts but agreements with the employer might include debt bondage or a commitment to work long term under unfair conditions and constant threat to some migrants. This group is characterised by the lack of Slovak language abilities, very high intensity of work, and concerns about engaging with the majority. All contact with the outside society thus takes place through mediators from within the community.

There is very little literature on the patterns of abuse and violence in spaces where household intersects with the workplace (see McGrath 2013). Our findings suggest the need to expand the focus of the developing debates on migration and labour-related violence (Waite et al. 2015) beyond the workplace and towards other spaces of migrant workers' lives. Also, there is a potential for a comparative understanding of the relations between the mechanisms behind work exploitation and domestic abuse of migrants (Raj and Silverman, 2002; Kasturirangan et al., 2004; Erez et al., 2009) that would help illuminate the overall patterns of vulnerability.

\section{CONCLUSIONS}

Addressing the lack of research into migration and social geographies of migration in East and Central Europe, this paper explored the livelihoods of migrants from non-EU countries in Slovakia, focusing on the experiences and constructions of violence, abuse and exploitation. The paper sought to contribute to the broader scholarship on migration experience in ECE, as well as to the emerging understandings of migration and vulnerability to violence. The following six conclusions overarch these themes and outline some further agenda for research.

First, the absence of migrants in ECE in the academic literature hides extensive patterns of serious and systematic abuse and exploitation. The paper demonstrated that the largely 
unexplored social realities of migrant experiences should drive the research on migration to ECE (cf. King and Mai 2008). However, even in the small cohort of migrants, as is the case of Slovakia, an in-depth scrutiny reveals significant differences in social backgrounds, economic practices and cultural experiences of migrant groups. Echoing King's warning against seeing what might be less noticeable cohorts of migrants as 'an undifferentiated mass' (King 2008, p.304), the paper calls for cautiousness about generalisations in theory, practice or policy, even if the very small numbers of migrants in comparison to other European countries might tempt this (see Barjaba and King 2005). Diverse patterns of livelihoods and vulnerabilities link to political, cultural and historical contexts of the post-socialist developments in ECE (Stenning and Hörschelmann, 2008), and require careful considerations of positionalities and politics of representations (Hörschelmann and Stenning, 2008).

Second, whilst a share of literature exists on particular forms of violence against migrants, there is less insight into the complexity of vulnerability to violence and abuse. Yet, the research demonstrated how several risk factors, such as lack of language skills, social capital, or cultural affiliation, underpin more than one form of violence and the relationships between the victim, abuser and other actors, including formal institutions or family and community. Also, different forms of violence can be intertwined in practice, such as labour exploitation and domestic abuse in the case of some migrant workers involved in family or community-run businesses. In the context of Slovakia, Ukrainian men, Thai women and some migrants from China and India are among the most vulnerable to both exploitation at the workplace and abuse in the household, whilst they also experience abuse and hate-motivated violence in public. Conceptually, the complex vulnerability to violence should be considered within the emerging views on migration and risk (Williams and Baláž, 2012) as well as vulnerability and exposure to violence (Spencer et al. 2003). In addition, effective policy and practical measures can be developed by considering the intersecting factors behind these dynamics of abuse.

Third, only few groups of migrants in our research proved to be at little risk of experiencing violence or abuse. These included particularly those whose employers provided them with additional assistance, often from professional agencies, or those in a close (marriage, family relationship) tie with a Slovak citizen. On the other hand, the research identified a variety of risk factors that are related to all three forms of violence addressed in this paper, including issues such as language skills, legal status, work contract, social capital, perception by the host society, cultural background, family status, financial means or gender, often intersecting and multiplying the exposure to violence. This means that even within the relatively small cohort of the non-EU documented migrant population in Slovakia, a majority of migrants need to be seen as at risk. These considerations might be even more pressing in other contexts with larger numbers of vulnerable migrants, and those with forms of violence occuring that we did not evidence in our research (such as widely prevalent gender-based sexual violence against migrants, see Keygnaert et al. 2012), or we did not focus on in the research itself (such as abuse of migrant children, see Alink et al., 2013) or this paper in particular (such as domestic violence). The findings suggest not to underestimate the diversity of forms and consequences of violence against migrants or to generalise individual experiences.

Fourth, the analysis revealed the pivotal role that public institutions with necessary capacities, professional and material, play in the prevention and intervention in violence against migrants. However, it also showed how a lack of trust from migrant communities and of the mutual 
bond then consequently represents a risk factor. This is particularly discernible for migrants from regions with a long history of bad experience with state institutions, such as those from Eastern Europe. Whereas community-based resources were instrumental for many migrants exposed to violence to cope with their realities, these are often inadequate or can lead to further exploitation, based on the dependence on community peers. Whilst multi-agency approaches to violence prevention, reduction and intervention are widely celebrated in many systems (Harwin et al., 1999; McGarell et al., 2010), our research advocates this perspective by additionally highlighting and evidencing the intersections between different forms of violence. This brings up the possibilities of an engagement of agencies with very little in common in their usual agendas, such as trade unions and domestic abuse shelters, who, together with vibrant migrant communities might establish a more powerful and multifaceted environment to combat violence against migrants.

Finally, the methodological discussion of the paper emphasises the importance of collaborative modes of research that involve practitioners, representatives from the migrant communities and other agents in reaching out to the most isolated and vulnerable groups of migrants in their diversity. I argued that this alliance was necessary for conducting the research in the required depth and breadth (cf. Ryan et al., 2011; Scott et al., 2012), but also that it multiplied the impact of the research project through the process of doing the research, not just as an outcome of the product, echoing the recent calls for creative and collaborative programmes of impact development and delivery (Pain et al., 2011).

Acknowledgement: This research was conducted while I worked at the International Organization for Migration and it was funded from the European Integration Fund (Grant nr. SK 2011 EIF P2/1 IP). Soňa Andrášová and Nina Paulenová equally contributed to the completion of the project, but the paper does not necessarily present IOM's views and the IOM takes no responsibility over the content. My thanks further go to Katarína Pevná for her invaluable help with the processing of the data, and to all research participants, migrant mediators and IOM colleagues. Finally, many thanks to Allan Findlay and Darren Smith, who commented on earlier drafts of the paper, and to two reviewers and Nicola Ansell, who helped shape the paper to its final form. 
Table 1 - Number of documented TCNs in Slovakia at 31.12.2011 (Source: Alien Police Department)

\begin{tabular}{|l|l|l|}
\hline Rank & Country of origin & Number of migrants \\
\hline 1 & Ukraine & 6091 \\
\hline 2 & Serbia & 4311 \\
\hline 3 & Russia & 2165 \\
\hline 4 & Vietnam & 1974 \\
\hline 5 & China & 1739 \\
\hline 6 & Republic of Korea & 1552 \\
\hline 7 & USA & 855 \\
\hline 8 & Macedonia & 540 \\
\hline 9 & Croatia & 457 \\
\hline 10 & Turkey & 341 \\
\hline 11 & India & 213 \\
\hline 12 & Belarus & 205 \\
\hline 13 & Libya & 192 \\
\hline 14 & Japan & 183 \\
\hline 15 & Afghanistan & 165 \\
\hline & & \\
\hline
\end{tabular}

Table 2 - Migrants' perception of violence and safety in Slovakia (Source: field survey)

\begin{tabular}{|l|l|l|l|l|}
\hline & $\begin{array}{l}\text { How safe do you } \\
\text { feel in Slovakia? } \\
\text { ('very safe' or } \\
\text { 'safe') }\end{array}$ & $\begin{array}{l}\text { Is violence a } \\
\text { problem in your } \\
\text { life in Slovakia? } \\
\text { ('serious } \\
\text { problem' or } \\
\text { 'problem') }\end{array}$ & $\begin{array}{l}\text { Has anyone in } \\
\text { Slovakia ever } \\
\text { committed any } \\
\text { violence against } \\
\text { you? } \\
\text { ('yes') }\end{array}$ & $\begin{array}{l}\text { How often do } \\
\text { you feel } \\
\text { threatened or in } \\
\text { danger in } \\
\text { Slovakia? } \\
\text { ('very often' or } \\
\text { 'often) }\end{array}$ \\
\hline $\begin{array}{l}\text { All migrants (\%) } \\
\begin{array}{l}\text { Eastern and } \\
\text { Southeastern } \\
\text { Europe (\%) }\end{array}\end{array}$ & 67 & 14 & 14 & 8 \\
\hline
\end{tabular}




\begin{tabular}{|l|l|l|l|l|}
\hline $\begin{array}{l}\text { Migrants from } \\
\text { Eastern and } \\
\text { Southeastern } \\
\text { Asia (\%) }\end{array}$ & 46 & 27 & 11 & 4 \\
\hline $\begin{array}{l}\text { Migrants from } \\
\text { Muslim countries } \\
\text { (\%) }\end{array}$ & 57 & 13 & 23 & 9 \\
\hline $\begin{array}{l}\text { Migrants from } \\
\text { African } \\
\text { countries, except } \\
\text { for Maghreb and } \\
\text { South Africa (\%) }\end{array}$ & 64 & 10 & 32 & 9 \\
\hline
\end{tabular}

Table 3 - Ratio of migrant victims of forced labour who have asked formal institutions for help (\%) (Source: field survey)

\begin{tabular}{|l|l|l|l|}
\hline & Never & Sometimes & Often or regularly \\
\hline Police & 49.2 & 38.4 & 12.3 \\
\hline $\begin{array}{l}\text { Doctor of medical } \\
\text { staff }\end{array}$ & 20.9 & 52.7 & 26.4 \\
\hline Embassy & 28.7 & 63.1 & 8.2 \\
\hline Helping organisations & 64.1 & 31.7 & 4.2 \\
\hline Church & 69.2 & 19.7 & 11.1 \\
\hline
\end{tabular}

Table 4 - Ratio of migrant victims of forced labour who were satisfied with help from formal institutions among those who have asked for it (\%) (Source: field survey)

\begin{tabular}{|l|l|l|l|}
\hline & Never & Sometimes & Often or regularly \\
\hline Police & 53.8 & 34.5 & 11.7 \\
\hline $\begin{array}{l}\text { Doctor of medical } \\
\text { staff }\end{array}$ & 24.1 & 39.3 & 36.7 \\
\hline Embassy & 31.8 & 51.2 & 16.9 \\
\hline Helping organisations & 56.2 & 26.2 & 17.6 \\
\hline Church & 69.7 & 17.3 & 13.0 \\
\hline
\end{tabular}

Table 5 - Ratio of migrant victims of domestic abuse who have asked formal institutions for help (in \%) (Source: field survey) 


\begin{tabular}{|l|l|l|l|}
\hline & Never & Sometimes & Often or regularly \\
\hline Police & 45.1 & 42.6 & 12.3 \\
\hline $\begin{array}{l}\text { Doctor of medical } \\
\text { staff }\end{array}$ & 21.1 & 41.6 & 37.3 \\
\hline Embassy & 31.6 & 55.3 & 13.1 \\
\hline Helping organisations & 43.8 & 42.1 & 14.1 \\
\hline Church & 56.3 & 35.8 & 7.9 \\
\hline
\end{tabular}

Table 6 - Ratio of migrant victims of domestic abuse who were satisfied with help from formal institutions among those who have asked for it (\%) (Source: field survey)

\begin{tabular}{|l|l|l|l|}
\hline & Never & Sometimes & Often or regularly \\
\hline Police & 56.3 & 36.1 & 7.6 \\
\hline $\begin{array}{l}\text { Doctor of medical } \\
\text { staff }\end{array}$ & 24.5 & 31.7 & 43.8 \\
\hline Embassy & 23.5 & 53.4 & 23.1 \\
\hline Helping organisations & 31.7 & 41.1 & 27.2 \\
\hline Church & 56.3 & 32.7 & 11.0 \\
\hline
\end{tabular}

Table 7 - Experiences of migrants with physical attacks motivated by hate (Source: field survey)

\begin{tabular}{|l|l|}
\hline Group of migrants & $\begin{array}{l}\text { Experience with physical attack motivated by } \\
\text { hate/perception of difference (\%) }\end{array}$ \\
\hline All migrants & 6.1 \\
\hline East and Southeast Europe & 4.6 \\
\hline East and Southeast Asia & 2.0 \\
\hline Muslim countries & 9.9 \\
\hline African countries & 18.7 \\
\hline
\end{tabular}

Table 8 - Experiences of migrants with verbal attacks (threats, insults) motivated by hate (Source: field survey)

Group of migrants Experience with physical attack motivated by hate/perception of difference (\%) 


\begin{tabular}{|l|l|}
\hline All migrants & 21.3 \\
\hline East and Southeast Europe & 23.9 \\
\hline East and Southeast Asia & 8.5 \\
\hline Muslim countries & 27.1 \\
\hline African countries & 37.5 \\
\hline Men from Ukraine & 36.6 \\
\hline
\end{tabular}

Table 9 - Experiences with the indicators of forced labour among all migrants and migrants from Ukraine (Source: field survey)

\begin{tabular}{|l|l|l|l|}
\hline Indicator (s) & $\begin{array}{l}\text { All } \\
\text { working } \\
\text { migrants }\end{array}$ & $\begin{array}{l}\text { Men from } \\
\text { Ukraine }\end{array}$ & $\begin{array}{l}\text { Women } \\
\text { from } \\
\text { Ukraine }\end{array}$ \\
\hline $\begin{array}{l}\text { More than one indicator - experience with forced } \\
\text { labour (\%) }\end{array}$ & 11.3 & 31.0 & 14.3 \\
\hline At least one indicator - high risk of forced labour (\%) & 29.2 & 51.7 & 33.3 \\
\hline Confinement at workplace (\%) & 12.5 & 37.9 & 7.7 \\
\hline Threats by the employer, boss (\%) & 5.1 & 10.3 & 5.3 \\
\hline Debts to the employer, boss (\%) & 9.2 & 13.8 & 13.2 \\
\hline $\begin{array}{l}\text { Reduction of the salary against the contract or no } \\
\text { salary for more than two months (\%) }\end{array}$ & 19.6 & 31.0 & 21.1 \\
\hline Passport taken away (\%) & 3.2 & 0.0 & 2.7 \\
\hline Threats of reporting to authorities (\%) & 8.1 & 25.9 & 11.1 \\
\hline
\end{tabular}

Table 10 - Experiences with other indicators of exploitative labour (Source: field survey)

\begin{tabular}{|l|l|}
\hline Indicator (s) & $\begin{array}{l}\text { All working } \\
\text { migrants }\end{array}$ \\
\hline $\begin{array}{l}\text { No Slovak language version of the contract (legally } \\
\text { required) (\%) }\end{array}$ & 22.3 \\
\hline Slovak version of the contract not understood (\%) & 24.7 \\
\hline Activities outside the contract required (\%) & 22.2 \\
\hline Wage below the minimal legal threshold (\%) & 7.3 \\
\hline
\end{tabular}




\begin{tabular}{|l|l|}
\hline More than 48 hours of work on average (\%) & 41.5 \\
\hline Injury at the workplace (\%) & 14.5 \\
\hline No or reduced annual or sick leave (\%) & 17.3 \\
\hline
\end{tabular}




\section{LIST OF REFERENCES}

Alink LRA, Euser S, van ljzendoorn MH, Bakermans-Kranenburg MJ. 2013. Is elevated risk of child maltreatment in immigrant families associated with socioeconomic status? Evidence from three sources. International Journal of Psychology 48(2): 117-127. DOI: 10.1080/00207594.2012.734622

Allamby L, Bell J, Hamilton J, Hansson U, Jarman N, Potter M, Toma S. 2011. Forced Labour in Northern Ireland. Exploiting Vulnerability. Joseph Rowntree Foundation: York.

Alvarado SE, Massey DS. 2010. In search of peace. structural adjustment, violence, and international migration in Mexico and Central America 1979-2002. The Annals of the American Academy of Political and Social Science 630(1): 137-161.

Anderson B, Ruhs M, Rogaly B, Spencer S. 2006. Fair Enough? Central and East European Migrants in Low-Wage Employment in the UK. Joseph Rowntree Foundation: York.

Anderson B, Rogaly B. 2005. Forced Labour and Migration to the UK. Trades Union Congress: London.

Balch A. 2012. Regulation and Enforcement to Tackle Forced Labour in the UK. A Systematic Response? Joseph Rowntree Foundation: York.

Barbeiro A, Spini D. 2011. Institutional violence towards immigrants, meaning making and lifecourse. intertwining biographical and historical timings. ISPP 2011 Proceedings.

BERR 2008. Vulnerable Worker Enforcement Forum. Final Report and Government Conclusions. Department for Business, Enterprise and Regulatory Reform: London.

Baláž V, Williams AM. 2007. Path-dependency and path-creation perspectives on migration trajectories. The economic experiences of Vietnamese migrants in Slovakia. International Migration 45(2): 37-67. DOI: 10.1111/j.1468-2435.2007.00403.x

Barjaba K, King R. 2005. Introducing and theorising Albanian migration. In The New Albanian Migration, King R, Mai N, Schwandner-Sievers S. (eds.); Sussex Academic Press: Brighton.

Barrell R, Fitzgerald J, Riley R. 2010. EU enlargement and migration. Assessing the macroeconomic impacts. Journal of Common Market Studies 48(2): 373-395. DOI: 10.1111/j.1468-5965.2009.02056.x

Benson P. 2008. EL Campo: Faciality and structural violence in farm labor camps. Cultural Anthropology 23(4): 589-629. DOI: 10.1111/j.1548-1360.2008.00020.x

Black R, Collyer M, Skeldon R, Waddington C. 2006. Routes to illegal residence: A case study of immigration detainees in the United Kingdom. Geoforum 37(4): 552-564. DOI: 10.1016/j.geoforum.2005.09.009 
Blazek M, Andrášová S, Paulenová N. 2013. Skúsenosti Migrantov a Migrantiek na Slovensku s Násilím [Experiences of Migrants in Slovakia with Violence]. International Organization for Migration: Bratislava.

Bloemraad I, Korteweg A, Yurdakul G. 2008. Citizenship and immigration. multiculturalism, assimilation, and challenges to the nation-state. Annual Review of Sociology 34(1): 1-27. DOI: 10.1146/annurev.soc.34.040507.134608

Brainard L, Jones A, Purvis N. (eds.) 2009. Climate Change and Global Poverty. A Billion Lives in the Balance? Brookings Institution Press: Washington.

Bromley RDF, Stacey RJ. 2012. Feeling unsafe in urban areas: exploring older children's geographies of fear. Environment and Planning A 44(2): 428-444. DOI: 10.1068/a44224

Brownlow A. 2005. A geography of men's fear. Geoforum 36(5): 581-592. DOI: 10.1016/j.geoforum.2004.11.005

Bryan A. 2009. The intersectionality of nationalism and multiculturalism in the Irish curriculum. teaching against racism? Race Ethnicity and Education 12: 297-317. DOI: $10.1080 / 13613320903178261$

Burnett J. 2013. Britain. racial violence and the politics of hate. Race and Class, Early view.

Burrell K. 2008. Materialising the border. spaces of mobility and material culture in migration from post-socialist Poland. Mobilities 3(3): 353-373. DOI: 10.1080/17450100802376779

Burrell K. 2010. Staying, returning, working and living key themes in current academic research undertaken in the UK on migration movements from Eastern Europe. Social Identities 16(3): 297-308. DOI: 10.1080/13504630.2010.482401

Careja R, Emmenegger P. 2012. Making democratic citizens. the effects of migration experience on political attitudes in Central and Eastern Europe. Comparative Political Studies 45(7): 871-898. DOI: 10.1177/0010414011428591

Castles S. 2006. Guestworkers in Europe. a resurrection? International Migration Review 40(4): 741-766. DOI: 10.1111/j.1747-7379.2006.00042.x

Castles S, Miller M. 2009. The Age of Migration. International Population Movements in the Modern World Fourth revised edition. Palgrave-Macmillan and Guilford Books: Basingstoke and New York.

Chakraborti N, Garland J. 2012. Reconceptualizing hate crime victimization through the lens of vulnerability and 'difference'. Theoretical Criminology 16 (4): 499-514. DOI: $10.1177 / 1362480612439432$

Cheong PH, Edwards R, Goulbourne H, Solomos J. 2007. Immigration, social cohesion and social capital. a critical review. Critical Social Policy 27: 24-49. DOI: 10.1177/0261018307072206 
Chudžíková A. 2011. Koncepcia homogenizácie spoločnosti svýhladom do roku 2020. Menšinová politika na Slovensku 03/2011: 11-12.

Cieslik A, 2011. Where Do You Prefer to Work? How the Work Environment Influences Return Migration Decisions from the United Kingdom to Poland. Journal of Ethnic and Migration Studies 379: 1367-1383. DOI: 10.1080/1369183X.2011.623613

Clark N. 2012. Detecting and Tackling Forced Labour in Europe. Joseph Rowntree Foundation: York.

Cohen JH. 2005. Remittance outcomes and migration. Theoretical contests, real opportunities. Studies in Comparative International Development 40(1): 88-112. DOI: 10.1007/BF02686290

Cooke J, Dwyer P, Waite L. 2010. The experiences of Accession 8 migrants in England. motivations, work and agency. International Migration 49(2): 54-79. DOI: 10.1111/j.14682435.2009.00595.x

Cook J, Dwyer P, Waite L. 2012. Accession 8 migration and the proactive and defensive engagement of social citizenship. Journal of Social Policy 41(2): 329-347. DOI: $10.1017 /$ S0047279411000766

Cook A. 2010. The expatriate real estate complex. creative destruction and the production of luxury in post-socialist Prague. International Journal of Urban and Regional Research 34(3): 611-628. DOI: 10.1111/j.1468-2427.2010.00912.x

Cook, A. 2011. Placing capitals. life-course transformations amongst expatriates in Prague. Area 43(4): 420-429. DOI: 10.1111/j.1475-4762.2010.00982.x

Coombes M, Champion T. 2006. Migration from the New Europe to the UK. assessing its regional and local impacts. 2006 European Population Conference Proceedings, Liverpool.

Craig G, Gaus A, Wilkinson M, Skrivankova K, McQuade A. 2007. Contemporary Slavery in the UK. Overview and Key Issues. Joseph Rowntree Foundation: York.

Dancygier RM. 2010. Immigration and Conflict in Europe. Cambridge University Press: Cambridge.

Divinský B. 2009. Migračné Trendy v Slovenskej Republike po Vstupe Krajiny do EÚ 2004 -2008. IOM: Bratislava.

Divinský B. 2011. Vybrané problémy migračného manažmentu Slovenskej republiky $v$ roku 2010. Migraceonline.cz, December 2011: 1-13.

Drbohlav D. 2003. Immigration and the Czech Republic with a special focus on the foreign labour force. International Migration Review 37(1): 194-224. DOI: 10.1111/j.17477379.2003.tb00134.x

Drbohlav D, Dzúrová D. 2007. Where are they going? Immigrant inclusion in the Czech Republic a case study on Ukrainians, Vietnamese, and Armenians in Prague. International Migration 45(2): 69-95. DOI: 10.1111/j.1468-2435.2007.00404.x 
Drbohlav D, Janská E. 2009. Illegal economic and transit migration in the Czech Republic intensive study of individual migrants' behaviour. Europe-Asia Studies: 61(1): 141-156. DOI: 10.1080/09668130802533025

Dwyer P, Hodkinson S, Wallace C, Stola D. (eds.) 2001. Patterns of Migration in Central Europe. Palgrave: London.

Dwyer P, Lewis H, Scullion L, Waite L. 2011. Forced Labour and UK Immigration Policy. Status Matters? Joseph Rowntree Foundation: York.

Ehrkamp P. 2008. Risking publicity: masculinities and the racialization of public neighborhood space. Social and Cultural Geography 9(2): 117-133. DOI: 10.1080/14649360701856060

Erel U. 2010. Migrating cultural capital. Bourdieu in migration studies. Sociology 44: 642-660. DOI: $10.1177 / 0038038510369363$

Erez $\mathrm{E}$, Adelman M, Gregory C. 2009. Intersections of immigration and domestic violence. Feminist Criminology 4(1): 32-56. DOI: 10.1177/1557085108325413

Ernst CW. (ed.) 2013. Islamophobia in America. The Anatomy of Intolerance. Palgrave Macmillan: London.

Fassman H, Haller M, Lane D. 2009. Migration and Mobility in Europe. Edward Elgar Publishing: Chelthenham and Camberley.

Felson RB, Paré P-P. 2005. The reporting of domestic violence and sexual assault by nonstrangers to the police. Journal of Marriage and Family 67(3): 597-610. DOI:

Fernandez-Esquer ME, Diamond PM. 2013. Intimate partner violence among stigmatized Latina workers. Journal of Interpersonal Violence 28(13): 2640-2656. DOI: $10.1177 / 0886260513487988$

Findlay A, Geddes A, McCollum D. 2010. International migration and recession. Scottish Geographical Journal 126(4): 299-320. DOI: 10.1080/14702541.2010.549346

FRA. 2012. Making Hate Crime Visible in the European Union. Acknowledging Victims' Rights. European Union Agency for Fundamental Rights: Luxembourg.

Galasińska A. 2010. Leavers and stayers discuss returning home. Internet discourses on migration in the context of the post-communist transformation. Social Identities 16(3): 309324. DOI: $10.1080 / 13504630.2010 .482416$

Geddes A, 2013. Forced Labour in the UK. Joseph Rowntree Foundation: York.

Glitz A. 2012. The labor market impact of immigration. a quasi-experiment exploiting immigrant location rules in Germany. Journal of Labor Economics 30(1): 175-213. DOI: $10.1086 / 662143$

Górny A, Kępińska E. 2004. Mixed marriages in migration from the Ukraine to Poland. Journal of Ethnic and Migration Studies 30(2): 353-372. DOI: 10.1080/1369183042000200740 
Gregory D. 2010. War and peace. Transactions of the Institute of British Geographers 35(2): 154-186. DOI: 10.1111/j.1475-5661.2010.00381.x

GRETA. 2011. Report Concerning the Implementation of the Council of Europe Convention on Action against Trafficking in Human Beings by the Slovak Republic. Council of Europe: Strasbourg.

Harwin N, Hague G, Malos E. 1999. Multi-Agency Approach to Domestic Violence: New Opportunities, Old Challenges? Whiting and Birch: London.

Hörschelmann K, Stenning A. 2008. Ethnographies of postsocialist change. Progress in Human Geography 32(3): 339-361. DOI: 10.1177/0309132508089094

Huang S, Yeoh BSA. 2007. Emotional labour and transnational domestic work: The moving geographies of 'maid abuse' in Singapore. Mobilities 2(2): 195-217. DOI: $10.1080 / 17450100701381557$

Human Rights First. 2008. 2008 Hate Crime Survey. Human Rights First: New York.

ILO. 2009. The Cost of Coercion. International Labour Organization: Geneva.

IOM. 2009a. Guidelines for the Collection of Data on Trafficking in Human Beings, Including Comparable Indicators. International Organization for Migration: Geneva.

IOM. 2009b. Working to Prevent and Address Violence Against Women Migrant Workers. International Organization for Migration: Geneva.

Jácome F. 2008. Trans-Mexican Migration. A Case of Structural Violence. London School of Economics: London.

Jewkes R, Levin J, Penn-Kekana L. 2002. Risk factors for domestic violence: findings from a South African cross-sectional study. Social Science and Medicine 55(9): 1603-1617. DOI: 10.1016/S0277-9536(01)00294-5

Kagan C, Lo S, Mok L, Lawthom R, Sham S, Greenwood M, Baines S. 2011 Experiences of Forced Labour among Chinese Migrant Workers. Joseph Rowntree Foundation: York.

Kalter F. 2011. Social capital and the dynamics of temporary labour migration from Poland to Germany. European Sociological Review 27(5): 555-569. DOI: 10.1093/esr/jcq025

Kasturirangan A, Krishnan S, Riger S. 2004. The impact of culture and minority status on women's experience of domestic violence. Trauma, Violence and Abuse 5: 318-332. DOI: $10.1177 / 1524838004269487$

Keygnaert I, Vettenburg N, Temmerman M. 2012. Hidden violence is silent rape. sexual and gender-based violence in refugees, asylum seekers and undocumented migrants in Belgium and the Netherlands. Cultural Health and Sexuality 14(5): 505-520. DOI: 10.1080/13691058.2012.671961 
King R. 2008. Across the sea and over the mountains. Documenting Albanian migration. Scottish Geographical Journal 119(3): 283-309. DOI: 10.1080/00369220318737179

King R, Mai N. 2011. Out of Albania. From Crisis Migration to Social Inclusion in Italy. Berghahn Books: London.

Klagge B, Klein-Hitpass K. 2010. High-skilled return migration and knowledge-based development in Poland. European Planning Studies 18(10), 1631-1651. DOI: 10.1080/09654313.2010.504346

Kloosterman R, Rath J. 2001. Immigrant entrepreneurship in advanced economies. mixed embeddedness further explored. Journal of Ethnic and Migration Studies 27: 189-202. DOI: $10.1080 / 13691830020041561$

Klvaňová R. 2010. Moving through social networks. the case of Armenian migrants in the Czech Republic. International Migration 48(2): 103-132. DOI: 10.1111/j.1468-2435.2009.00565.x

Koskela H. 1997. "Bold walks and breakings": Women's spatial confidence versus fear of violence. Gender, Place and Culture 4(3): 301-320. DOI: 10.1080/09663699725369

Lawrence BB, Karim A. 2007. General introduction: theorizing violence in the twenty-first century. In On Violence: A Reader, Lawrence BB, Karim, A. (eds) Duke University Press, Durham NC.

Longhi S, Nijkamp P, Poot J. 2010. Meta-analyses of labour-market impacts of immigration. key conclusions and policy implications. Environment and Planning C 28(5): 819-833 DOI: 10.1068/c09151r

Manevska K, Achterberg P. 2011. Immigration and perceived ethnic threat. cultural capital and economic explanations. European Sociological Review, Advance Access.

Maroukis T, Iglicka K, Gmaj K. 2011. Irregular migration and informal economy in Southern and Central-Eastern Europe. breaking the vicious cycle. International Migration 49(5), 129-156. DOI: $10.1111 / \mathrm{j} .1468-2435.2011 .00709 . x$

Martin R, Radu D. 2012. Return migration. the experience of Eastern Europe. International Migration 50(6): 109-128. DOI: 10.1111/j.1468-2435.2012.00762.x

McClintock M. 2005 Everyday Fears. A Survey of Violent Hate Crimes in Europe and North America. Human Rights First: New York.

McCollum D, Findlay AM. 2011. Trends in A8 migration to the UK during the recession. Population Trends 145(1): 1-13. DOI: 10.1057/pt.2011.18

McGarrell EF, Corsaro N, Hipple NK, Bynum TS. 2010. Project safe neighborhoods and violent crime trends in US cities: assessing violent crime impact. Journal of Quantitative Criminology 26(2): 165-190. DOI: 10.1007/s10940-010-9091-9

McGrath S. 2013. Many chains to break. the multi-dimensional concept of slave labour in Brazil. Antipode 45(4): 1005-1028. DOI: 10.1111/j.1467-8330.2012.01024.x 
Medová L, Drbohlav D. 2013. Estimating the size of the irregular migrant population in Prague - an alternative approach. Tijdschrift voor Economische en Sociale Geografie 104(1): 75-89. DOI: 10.1111/j.1467-9663.2012.00737.x

Mehta A, Bondi L. 1999. Embodied discourse: on gender and fear of violence. Gender, Place and Culture 6(1): 67-84. DOI: 10.1080/09663699925150

Meyer JB. 2001. Network approach versus brain drain. lessons from the diaspora. International Migration 39(5): 91-110. DOI: 10.1111/1468-2435.00173

Moukarbel N. 2009. Sri Lankan Housemaids in Lebanon. A Case of 'Symbolic Violence' and 'Everyday Forms of Resistance'. Amsterdam University Press: Amsterdam.

O'Connell Davidson J. 2013. Troubling freedom. migration, debt, and modern slavery. Migration Studies 1(2): 176-195. DOI: 10.1093/migration/mns002

Pain, R. 1997. Social geographies of women's fear of crime. Transactions of the Institute of British Geographers 22(2): 213-244. DOI:

Pain, R. 2001. Gender, race, age and fear in the city. Urban Studies 38(5-6): 899-913. DOI: $10.1080 / 00420980120046590$

Pain, R. 2006. Paranoid parenting? Rematerializing risk and fear for children. Social and Cultural Geography 7(2): 221-243. DOI: 10.1080/14649360600600585

Pain R. 2014. Seismologies of emotion : fear and activism during domestic violence. Social and Cultural Geography 15(2): 127-150. DOI: 10.1080/14649365.2013.862846

Pain R, Kesby M, Askins K. 2011. Geographies of impact : power, participation and potential. Area 43(2): 183-188. DOI: 10.1111/j.1475-4762.2010.00978.x

Pikhart H, Drbohlav D, Dzurova D. 2010. The self-reported health of legal and illegal/irregular immigrants in the Czech Republic. International Journal of Public Health 55(5): 401-411. DOI: 10.1007/s00038-010-0156-1

Rabrenovic G. 2007. When hate comes to town. community response to violence against immigrants. American Behavioral Scientist 51(2): 349-360. DOI: 10.1177/0002764207306063

Rafferty Y. 2013. International dimensions of discrimination and violence against girls: A human rights perspective. Journal of International Women's Studies 14(1): 1-5. DOI:

Raj A, Silverman J. 2002. Violence against immigrant women. The roles of culture, context, and legal immigrant status on intimate partner violence. Violence Against Women 8: 367-398. DOI: $10.1177 / 10778010222183107 \mathrm{t}$

Raleigh CA. 2011. The search for safety. the effects of conflict, poverty and ecological influences on migration in the developing world. Global Environmental Change 21(1): 82-93. DOI: 10.1016/j.gloenvcha.2011.08.008

Reed E, Silverman JG, Ickovics JR, Gupta J, Welles SL, Santana MC, Raj A. 2010. Experiences of racial discrimination \& relation to violence perpetration and gang involvement among a 
sample of urban African American men. Journal of Immigrant and Minority Health 12(3): 319326. DOI: 10.1007/s10903-008-9159-x

Ryan L, Kofman E, Aaron P. 2011. Insiders and Outsiders: working with peer researchers in researching Muslim communities. International Journal of Social Research Methodology 14(1): 49-60. DOI: 10.1080/13645579.2010.481835

Sabates-Wheeler R, Waite M. 2003. Migration and Social Protection. A Concept Paper. Institute of Development Studies: Sussex.

Sandberg L, Tollefsen A. 2010. Talking about fear of violence in public space: Female and male narratives about threatening situations in Umeå, Sweden. Social and Cultural Geography 11(1): 1-15. DOI: $10.1080 / 14649360903420178$

Shechory M, Ben-David M, Soen D. (eds) 2010. Who Pays the Price? Foreign Workers, Society, Crime and the Law. Nova Science Publishers: Hauppauge NY.

Scott S, Craig G, Geddes A. 2012. Experiences of Forced Labour in the UK Food Industry. Joseph Rowntree Foundation: York.

Shernock, S. 2005. Third party roles in intimate partner violence incidents and their effects on police response in a statewide rural jurisdiction. Journal of Police and Criminal Psychology 20(1): 22-39. DOI: 10.1007/BF02806704

Skrivankova K. 2006. Trafficking for Forced Labour. UK Country Report. Anti-Slavery International: London.

Skrivankova K. 2010. Between Decent Work and Forced Labour. Examining the Continuum of Exploitation. Joseph Rowntree Foundation: York.

Spencer MB, Dupree D, Cunningham M, Harpalani V, Munoz-Miller M. 2003. Vulnerability to violence: A contextually-sensitive, developmental perspective on African American adolescents. Journal of Social Issues 59(1): 33-49. DOI: 10.1111/1540-4560.t01-1-00003

Spencer S, Ruhs M, Anderson B, Rogaly B. 2007. Migrants' Lives Beyond the Workplace - The Experiences of Central and East Europeans in the UK. Joseph Rowntree Foundation: York.

Stenning A, Dawley S. 2009. Poles to Newcastle. grounding new migrant flows in peripheral regions. European Urban and Regional Studies 16(3): 273-294. DOI: $10.1177 / 0969776409104693$

Stenning A, Hörschelmann K. 2008. History, geography and difference in the post-socialist world. or, do we still need post-socialism? Antipode 40(2): 312-335. DOI: 10.1111/j.14678330.2008.00593.x

Triandafyllidou A. 2009. Migrants and ethnic minorities in post-communist Europe. negotiating diasporic identity. Ethnicities 9(2): 226-245. DOI: 10.1177/1468796809103461

UNODC. 2012. Global Report on Trafficking in Persons. United Nations Office on Drugs and Crime: Vienna. 
US State Department. 2012. Trafficking in Persons Report 2012. US State Department: Washington.

Van Liempt I, Bilger V. (eds.) 2009. The Ethics of Migration Research Methodology - Dealing with Vulnerable Migrants. Sussex Academic Press: Eastbourne.

Van Liempt I, Bilger V. 2012. Ethical challenges in research with vulnerable migrants. In Handbook of Research Methods in Migration Vargas-Silva C. (ed.); Edward Elgar Publishing: Cheltenham.

Vermeersch P. 2007. A minority at the border. EU enlargement and the Ukrainian minority in Poland. East European Politics and Societies 21(3): 475-502. DOI: $10.1177 / 0888325407303793$

Waite L, Dwyer P, Hodkinson S, Lewis H. 2013. Precarious Lives. Forced Labour, Exploitation and Asylum. Policy Press: Bristol.

Waite LJ, Lewis H, Craig G, Skrivankova K. (eds) 2015. Vulnerability, Exploitation and Migrants: Insecure Work in a Globalised Economy. Palgrave: London.

Wayland SW. 2011. Immigration Self-Employment and Entrepreneurship in the GTA. Metcalf Foundation: Toronto.

Welch R. 1989. A Feminist Ethic of Risk. Fortress Press: Minneapolis.

WHO. 2002. World Report on Violence and Health. World Health Organization: Geneva.

Williams AM, Baláž V. 2004. From Private to public sphere, the commodification of the au-pair experience? Returned migrants from Slovakia to the UK. Environment and Planning A 36(10): 1813-1833. DOI: 10.1068/a36279

Williams AM., Baláž V. 2005a. Vietnamese community in Slovakia. Sociologica-Slovak Sociological Review 37: 249-274.

Williams AM., Baláž V. 2005b. What human capital, which migrants? Returned skilled migration to Slovakia from the UK. International Migration Review 39(2): 439-468. DOI: 10.1111/j.1747-7379.2005.tb00273.x

Williams AM., Baláž V. 2008. International mobility, learning and knowledge transfer. a case study of Slovak doctors. Social Science and Medicine 67(11): 1924-1933. DOI: 10.1016/j.socscimed.2008.09.003

WIlliams AM, Baláž V. 2012. Migration, risk, and uncertainty. theoretical perspectives. Population, Space and Place 18(2): 167-180. DOI: 10.1002/psp.663 